\title{
EXPLORING THE INFLUENCE OF EXECUTIVE MANAGEMENT DIVERSITY ON IT GOVERNANCE
}

\author{
Sylvie Héroux (D) https://orcid.org/0000-0002-8677-663X \\ Anne Fortin (D) https://orcid.org/0000-0001-5727-8650 \\ Accounting Department, École des sciences de la gestion, Université du Québec à Montréal \\ (ESG-UQAM), Montréal, Québec, Canada
}

\begin{abstract}
As all organizations are attaching more strategic importance to information technology (IT), IT governance has gained researchers' interest. In fact, a large body of literature focuses on firm-specific or executive management attributes such as leadership as determinants of IT governance. However, it is still relevant to identify other factors influencing IT governance. Since executive management demographics and demographic diversity have an impact on strategic decisions, we explore the influence of executive management diversity on IT governance. Results suggest that IT governance for a high educationalhigh tenure diversity profile differs significantly from that for a low industry-moderate tenure diversity profile and a high industry-low tenure diversity profile. Furthermore, IT governance structures differ according to executive management diversity profile more than IT governance processes and relational mechanisms.
\end{abstract}

Keywords: IT governance, executive management diversity, educational background, functional background, industry background, tenure

Manuscript first received: 2017/Aug/22. Manuscript accepted: 2017/Dec/13

Address for correspondence:

Sylvie Héroux, Professor, Accounting Department, École des sciences de la gestion, Université du Québec à Montréal (ESG-UQAM), C.P. 8888 Succ. Centre-Ville, Montréal, Québec H3C 3P8, Canada.

E-mail: heroux.sylvie@uqam.ca

Anne Fortin, Professor, Accounting Department, École des sciences de la gestion, Université du Québec à Montréal (ESG-UQAM), C.P. 8888 Succ. Centre-Ville, Montréal, Québec H3C 3P8, Canada.

E-mail : fortin.anne@uqam.ca 


\section{INTRODUCTION}

Information technology (IT) governance is considered a sub-set of corporate governance (Lunardi et al., 2014; Pereira \& Mira da Silva, 2012; Webb, 2006). As an integral part of corporate governance (De Haes \& Van Grembergen, 2013; Mohamed \& Gian Singh, 2012), IT governance is the responsibility of the board of directors and the executive (ITGI, 2003). It helps organizations manage risk from technology-related losses (Mohamed \& Gian Singh, 2012) and determine whether they are getting value from their IT investments (Weill and Ross, 2004, in Bradley et al., 2012). Since organizations are increasingly relying on IT to enhance their business performance (Scheeren et al., 2013; Wilkin \& Chenhall, 2010), IT governance has become an important strategic issue.

In other words, as a strategic choice, IT governance helps organizations manage IT investments (Xue et al., 2008, in Bradley et al., 2012). Interest in IT governance is growing (Heindrickson \& Santos, Jr, 2014) as both public and private organizations are attaching more and more strategic importance to IT. Furthermore, evaluating and improving IT governance has become crucial since it allows organizations to monitor the effectiveness of their ITs (Pérez Lorences \& Garcia Avila, 2013). "Just as corporate governance has been driven by the imperative to manage firms' operations to more effectively meet shareholder expectations (...), so have firms focused on ITG [IT governance] to achieve similar IT accountabilities" (Wilkin \& Chenhall, 2010, p. 108). In that context, it is relevant to examine factors that could influence IT governance.

Prior research has generally stressed the strategic and growing importance of IT governance in all organizations. More specifically, as the next section of this paper shows, a large body of IT governance literature is directed towards firm-specific or executive management attributes such as leadership or commitment as determinants of IT governance. However, it remains relevant to pursue the identification of other factors impacting IT governance. Considering the abundant literature on the influence of executive management demographics and demographic diversity on strategic decisions, and the fact that, to our knowledge, no studies have been conducted on executive management diversity as an antecedent of IT governance, the aim of this study is to explore the degree of use of IT governance mechanisms across executive management demographic diversity profiles.

Our study contributes to IT governance literature by providing new insights into antecedents of IT governance. Based on our sample, we developed three demographic diversity profiles showing that different "mixes" of executive management insights and knowledge gained through education, experience from industry background and tenure can produce different outcomes in terms of the degree of use of IT governance mechanisms. Organizations could determine which of these profiles suits them best in light of their IT governance needs. A mix of high education and high tenure diversity would seem to be favorable to the development of organizations seeking to improve their IT governance.

\section{LITERATURE REVIEW}

A number of prior studies have investigated antecedents of IT governance. For instance, Xue et al. (2008) analyze the following three categories of factors influencing IT governance: characteristics of IT investments, external environment (competitive pressures, institutional forces, external resources) and internal context (organizational centralization, IT function power). Building on Brown and Grant (2005) and Xue et al. (2008), Pereira and Mira da Silva (2012) summarize contingency factors of IT governance implementation, including organizational culture, structure, strategy, size, industry, 
regional differences, maturity, ethical awareness in corporate governance, and trust (to minimize governance failure).

Based on research published between 2000 and 2010, Mohamed and Gian Singh (2012) identify five groups that serve as determinants of IT governance as follows: organizational demographics (organization size and age); information intensity (IT intensity varies by industry); organizational culture (set of assumptions, understandings, and implicit rules that govern day-to-day behavior in the workplace); external environment characteristics (environmental uncertainty); and IT function characteristics ( size of IT budget or IT department, IT function maturity). In addition to the antecedents of IT governance identified by Xue et al. (2008), Tallon et al. (2014) highlight the following: context (project, stakeholder, global) and information systems (IS) project phase; organizational structure; corporate governance economies of scope; IT absorptive capability; historical operations; and environmental uncertainty. In brief, a large body of IT governance literature addresses firm-specific determinants of IT governance. In light of Buchwald et al. (2014), they can be labeled as internal or external organizational factors, depending on whether their focus points are inside or outside the organization.

Other studies have examined group-specific antecedents of IT governance by highlighting the strategic role of the executive management team. ${ }^{1}$ Results suggest that executive management support influences IT-related strategic decisions such as IT adoption (Bruque-Camara et al., 2004; Jeyaraj et al., 2006) and Internet adoption (Teo \& Pian, 2003). Furthermore, a close relationship between the CEO and the CIO is linked to stronger executive management support for IT-enabled strategic initiatives (Wilkin \& Chenhall, 2010) and more effective IT governance (Wilson \& Pollard, 2009). In fact, executive management support is important to achieve IT-business alignment (Martin et al., 2005; Weill \& Ross, 2004; Wilson \& Pollard, 2009).

Moreover, executive management involvement in IT decision-making through an IT steering committee or IT-related communication policies influences the effectiveness of IT governance practices (Huang et al., 2010). Executive management involvement and support are the most significant success factors of IT governance performance (Nfuka \& Rusu, 2011). Executive management commitment to IT investments and to IT's role in organizational competitiveness influences the strategic value of IT (Neirotti \& Paolucci, 2007). What's more, "the greater the top management commitment, the greater the ITG success"'2 (Buchwald et al., 2014, p. 140). Strong and committed executive management leadership supports the evolution and application of IT governance through clear organizational direction or strategies (Wilson \& Pollard, 2009). Overall, executive management involvement seems to contribute to IT governance effectiveness (Ali et al., 2013). In view of these results, executive management appears to enhance IT governance through its leadership, involvement/participation in, support, and commitment to IT-related strategic choices. However, as pointed out by Bradley et al. (2012), the effectiveness of executive management support and participation could be affected by the characteristics of the executive management team (Carpenter et al., 2004; Hambrick \& Mason, 1984).

\footnotetext{
1 Prior studies refer to the group of individuals involved in strategic decision making at the upper echelons/highest level of an organization as the "top management team" (e.g., Boerner et al., 2011; Carpenter et al., 2004; Hambrick \& Mason, 1984; Li, 2013; Simons et al., 1999; Wu et al., 2011), "senior management" (e.g., Nfuka \& Rusu, 2011; Wilson \& Pollard, 2009), the "board as a firm's management team" (Midavaine et al., 2016), the "C-suite management level (e.g., CEO, COO, CFO and CIO)" (Ali et al., 2013), and "top executives" (Li, 2013; Tallon, 2014). In this study, we use the expression "executive management" when we refer to the group of individuals that includes the CEO, the CIO and other senior executives.

2 Top management commitment refers to the "extent to which top management promotes the [IT governance] activities by means of steering, communicating, providing resources, and advising," while [IT governance] success is defined as the "extent to which a clearly defined and transparent set of structures, processes, and standards exists that is accepted throughout the organization and integrated into the daily work routines" (Buchwald et al., 2014, p. 143).
} 
Based on the upper echelon theory, organizations are viewed as reflections of their executives' cognitive bases, which are proxied by demographics such as age, gender, functional background and tenure (Hambrick \& Mason, 1984). Given this theoretical perspective, a large number of studies analyze the influence of executive management demographics on various topics such as business strategy (Goll et al., 2008), firm performance (Stone \& Tudor, 2005), firm growth (Colombelli, 2015), innovation (Balta et al., 2013), and value chain management (i.e., the cumulative and variety of actions taken by a firm) (Agnihotri, 2014). Moreover, the impact of executive management diversity/ heterogeneity (demographic diversity) has been a topic of interest in studies on firm performance (Awino, 2013; Boerner et al., 2011; Boone \& Hendricks, 2009; Simons et al., 1999), innovation (Li, 2013) and strategic decisions (Eisenhardt et al., 1997; Knight et al., 1999; Miller et al., 1998). In general, and as shown by Carpenter et al. (2004), who present key results from about 30 empirical upper-echelon studies published from 1996 to 2004, there is abundant literature on executive management demographics and demographic diversity.

In spite of this large body of literature, a limited number of studies investigate the influence of executive management characteristics on IT governance in particular (e.g., executive management's knowledge of IT governance in Ali et al., 2013; and executive management's frames of reference in relation to IT in Bruque \& Moyano, 2007, as indicated in Newby et al., 2014). Furthermore, to our knowledge, no studies have as yet examined the influence of executive management diversity on IT governance. This is the objective of this study.

\section{CONCEPTUAL BACKGROUND AND PROPOSITIONS}

In this section, we first define IT governance and executive management diversity as our main constructs. Based on upper echelon and diversity literatures, we then develop our research propositions.

\section{IT governance}

Based on research published between 1994 and 2010, a consensus definition of IT governance is still lacking (Mohamed \& Gian Singh, 2012; Pereira \& Mira da Silva, 2012). However, while many definitions of IT governance have been put forward (Simonsson \& Johnson, 2005; Pereira \& Mira da Silva, 2012), the following is one of the most commonly used (Nufka \& Rusu, 2011).

IT governance is the responsibility of the board of directors and executive management. It is an integral part of enterprise governance and consists of the leadership and organisational structures and processes that ensure that the organisation's IT sustains and extends the organisation's strategies and objectives. (ITGI, 2003, p. 10)

In other words, IT governance "addresses the definition and implementation of processes, structures and relational mechanisms in the organization that enable both business and IT people to execute their responsibilities in support of business/IT alignment and the creation of business value from IT-enabled investments" (De Haes \& Van Grembergen, 2013, p. 61). This suggests that IT governance is comprised of the following three dimensions: structures, processes and relational mechanisms (Nufka \& Rusu, 2011). 
Structures are defined as formal positions, roles for IT-related decision-making (Bowen, et al., 2007; Peterson, 2004) and committees and councils (Peterson, 2004). Processes, which refer to strategic IT decision making/monitoring (Peterson, 2004), emphasize the implementation of IT management techniques and procedures (Bowen et al., 2007). The structures and processes "tend to be mandatory, tangible, and often implemented in a top-down manner" (Peterson 2004, p. 15). They are complemented by relational mechanisms that involve IT leadership and other mechanisms such as partnerships and informal meetings between business and IT executives, job rotation and cross training between IT staff and business people (De Haes \& Van Grembergen, 2009).

\section{Executive management diversity}

Pelled (1996) proposes that different types of demographic diversity variables are represented within a group. More specifically, she describes two approaches that have been used to study demographic diversity:

One approach has been to treat it broadly, making statements about heterogeneity or homogeneity in general, rather than about a particular type (e.g., age diversity). (...) The second approach has been to treat each demographic diversity variable as a distinct theoretical construct based on the argument that different types of diversity may produce different outcomes. (Pelled, 1996, p. 618)

Based on this second approach, on the one hand, Pelled (1996) classifies group tenure, organizational tenure and education and functional backgrounds as highly (and similarly) job-related since they are "directly shaping task perspectives and technical skills" (p. 619). On the other, she considers age, gender and race as low in job-relatedness since they do not shape these perspectives and skills as directly as tenure and education and functional backgrounds.

In the same vein, Midavaine et al. (2016) examine the influence of two types of management team diversity on R\&D investment: information-based diversity (education and tenure) and personalbased diversity (age, gender). Information-based diversity refers to cognitive abilities; that is, to attributes reflecting managers' ability to select and process relevant information (Midavaine et al., 2016).

In this study, we explore whether different types of executive management diversity are associated with the various categories of IT governance mechanisms, as well as with specific mechanisms. Drawing on Pelled (1996) and Midavaine et al. (2016), we take the approach that different types of diversity can produce different outcomes. We focus on job-related/information-based demographic diversity variables since some dimensions of diversity such as age and gender are less relevant to strategic decision-making than experience and tenure (Simons et al., 1999). More specifically, we examine diversity in terms of educational background, functional background, industry background and tenure.

Educational background consists of the various disciplines in which an executive has studied (e.g., accounting, business, law, engineering, arts and humanities). Functional background encompasses all the categories in which an executive has functional experience (e.g., finance/accounting, production/ operations, information systems/IT), while industry background reflects all the categories in which each executive has industry experience (e.g., manufacturing, telecommunications/IT/media). 
Executive management tenure is defined as the number of years each executive has served on the executive team.

\section{Influence of executive management diversity on IT governance}

In this section, we suggest that sharing a diversity of cognitive bases, proxied by knowledge and insights gained through education, as well as experience from functional and industry backgrounds and tenure, could influence IT governance.

Positive outcomes can derive from heterogeneous groups since diversity makes it possible to build on insights from individuals (Surowiecki, 2005, in Tallon, 2014). For instance, diversity of executive management increases its ability to handle strategic change (Hambrick \& Mason, 1984), can help this team generate alternative solutions (Bantel \& Jackson, 1989), and has often been considered a key driver of innovation (Qian et al., 2013).

However, since heterogeneous groups do not fully share cognitive models that could facilitate a common understanding of situations they face, conflicts may arise. Yet decision-making conflict at senior levels is essential for effective strategic choice (Eisenhardt et al., 1997). Thus, despite potential conflicts between executives, diversity can broaden executive management's range of viewpoints, which is beneficial since executives are frequently confronted with ambiguous, extremely uncertain and high-stake situations (Eisenhardt et al., 1997). In other words, even though executive management diversity may spark conflicts and disagreements, it encourages these executives to consider a wider range of solutions to problems. Accordingly, in terms of IT-related strategic decision making, considering the whole body of opinion across all executives in the same organization may be more useful (Tallon, 2014). Even if all executives are not in complete agreement, it is crucial that they reach a consensus on the perceived value of IT (Tallon, 2014).

Executive management's knowledge of its business and an understanding of IT issues are important to achieve IT-business alignment (Wilson \& Pollard, 2009). More specifically, executive management with an adequate base of prior IT governance knowledge is more qualified to lead and control IT governance, and better at aligning business and IT (Ali et al., 2013). In this study, we assume that executive management's prior relevant knowledge of IT governance structures, processes and relational mechanisms could be built on executive management diversity in terms of educational, functional or industry backgrounds and tenure.

With their specific educational backgrounds (Karanja \& Zaveri, 2012), skills (i.e., the ability to execute IT leadership and successfully deliver strategic IT projects) (Blaskovich \& Mintchik, 2011) and managerial capabilities (Heart et al., 2010), IT executives/CIOs can help develop executive management's IT governance knowledge since these managers interact with non-IT executives. This suggests that functional as well as educational diversity is important in building an executive management team with IT governance knowledge. For example, an appropriate mix of business and IT executives can be beneficial to organizations as it contributes to strategic alignment, a balanced IT investment portfolio and close coordination of business and IT (Bowen et al., 2007).

Long tenure can enhance executives' knowledge of what a firm is able to do, while shorter tenure may help determine what an organization should do (Midavaine et al., 2016). Moreover, as the key members of executive management (Taniman \& O'Shannassy, 2015), long-tenured CEOs may have little interest in implementing organizational changes because they are more committed to implementing their own view when running the organization (Barker \& Mueller, 2002). As a result, "by combining the experience and knowledge of the company that long tenured executive management 
team members have with new knowledge and fresh insights lesser tenured individuals may bring to the organization, new knowledge may emerge" (MacCurtain et al., 2010, p. 224). Accordingly, in the context of our study, IT governance-related decisions could benefit from executive management tenure diversity. New executives, whether they come from inside or outside the organization, could bring new ideas about the implementation of IT governance mechanisms.

In addition, in stable industries, throughput-function experience (e.g., accounting, process engineering, production) is positively associated with profitability (Hambrick \& Mason, 1984). However, in turbulent industries, it is output function experience (e.g., such as product R\&D, marketing, sales) that is associated with profitability (Hambrick \& Mason, 1984). For instance, firm performance declined steadily across CEOs' tenures in the computer industry, as their paradigms grew obsolete more quickly than they could learn (Henderson et al., 2006).

These results suggest that interactions between tenure or functional background and industry background can produce different outcomes in terms of performance. In this study, it is reasonable to assume that executives with a dynamic industry background such as telecommunications/IT/media may have a different perspective than those with experience, for example, in the stable food industry when assessing the importance and urgency of implementing IT governance mechanisms in their organization. Therefore, executive management diversity in industry background may influence IT governance-related decisions in terms of structures, processes and relational mechanisms to put in place.

In short, greater executive management diversity can make the implementation of IT governance structures, processes and relational mechanisms more difficult since executives can have various sources of cognitive bias that could lead to different or conflicting opinions about IT business value. However, organizations benefit from various executives' insights to enhance IT governance mechanisms. More specifically, organizations that need to implement a set of IT governance mechanisms to ensure their IT-business alignment could draw upon diverse executive management knowledge and experience gained through educational, functional and industry backgrounds and tenure.

Bringing together these insights from both upper echelon and diversity literatures, and based on the assumption that different types of diversity can produce different outcomes (Pelled, 1996; Midavaine et al., 2016), we refer to "executive management diversity profiles" as various possible combinations of these types of diversity. We thus expect that the degree of use of IT governance mechanisms will differ according to executive management diversity profile. This leads us to explore the following propositions:

Proposition 1: The degree of use of IT governance mechanisms will differ according to executive management diversity profile.

More specifically:

Proposition 2: The degree of use of specific IT governance mechanisms will differ according to executive management diversity profile.

\section{RESEARCH METHOD}

We used a mail survey to collect data on IT governance since it relates to internal organizational matters. The questionnaire was sent to the senior executives/officers in charge of IT (Vice-president [VP] IT, CIO, Manager or Director in charge of technology, or Chief Technology Officer) in a 
sample of Canadian organizations. We obtained contact information for target organizations from the 2014 Financial Post 500 database and occasionally from corporate websites. When the name of the executive in charge of IT was not available, we sent the survey to the President/CEO requesting that the questionnaire be completed by the top manager with an overview or sufficient knowledge of the organization's IT governance and IT strategic issues.

The questionnaire included questions about IT governance mechanisms and IT intensity. Questions relevant to the description of the respondents and their organizations were also included (number of employees in the organization and the IT function, respondents' number of years of professional experience, their position and educational background). The questions were selected/ adapted from existing instruments and the questionnaire was pretested by three IT executives/ directors. The English version was translated into French as some targeted participants were French speaking. Both versions of the questionnaire, which took approximately 30 minutes to complete, were revised by two academics and a translator. ${ }^{3}$ We obtained ethics approval from the institution's Research Ethics Committee.

The information on executive management diversity was obtained from Boardex, using the annual information form and corporate websites as complements. Since the questionnaires were assigned a tracking number, we were able to match the responses to the respondents' organization. Data on assets, revenues, net income and market capitalization were obtained from Compustat or from organizations' financial statements posted on their website or on SEDAR, the electronic system for the official filing of documents by public companies across Canada.

\section{Target population and survey implementation}

To identify our initial target population of Canadian publicly traded and for-profit paragovernmental organizations, we used the 2014 Financial Post 500 database, which contains information on Canada's Top 800 private and public organizations. Private companies in this database were not selected since executive management diversity data is not available from public sources. The final target population was comprised of 362 organizations (after excluding organizations with all their business outside Canada, Canadian subsidiaries of foreign companies with IT governance outside Canada, holdings, closed-end funds, etc.).

The survey administration procedures, which were implemented between April and July 2015, included pre-notice by email, an original mailing followed by a reminder card, and a second mailing to non-respondents (Dillman, 2000). These procedures were followed up by phone contacts or voice messages to targeted respondents or administrative assistants, and finally by a third mailing to nonrespondents. Along with the questionnaire, the mailing included a cover letter assuring respondents of the confidentiality of their responses and a self-addressed postage-paid envelope.

\section{Sample}

A total of 67 usable questionnaires were received, for an $18.5 \%$ response rate, ${ }^{4}$ which is higher than or comparable to that of other survey studies among senior executives/officers in charge of IT

3 The questionnaire included questions on other matters not relevant to this study. Relevant questions are shown in the tables.

4 Email correspondence with some of the targeted respondents provided motives for non-responses. Some pointed to an organizational policy prohibiting answering questionnaires. Others mentioned lack of time to fill out the questionnaire. 
Table 1. Sample firms' and respondents' characteristics

\begin{tabular}{|c|c|c|c|c|c|c|}
\hline \multicolumn{7}{|c|}{ Panel A: Organizations' size and performance } \\
\hline Variables & $\mathrm{N}$ & Mean & Median & Std Dev. & Min. & Max. \\
\hline \multicolumn{7}{|l|}{ Size } \\
\hline \multicolumn{7}{|l|}{ Number of employees } \\
\hline In total & 64 & 9350.2 & 1600.0 & $19,255.7$ & 26 & 85,000 \\
\hline In IT function & 64 & 633.4 & 54.0 & 1983.9 & 1 & 12,000 \\
\hline Market value $e^{a, b}$ & 50 & $10,374,182$ & 990,540 & $25,715,772$ & 31,978 & $115,464,431$ \\
\hline Assets $^{\mathrm{a}}$ & 64 & $65,660,067$ & $2,002,502$ & $203,875,498$ & 113,610 & $944,742,000$ \\
\hline Revenues $^{\mathrm{a}}$ & 64 & $5,190,361$ & $1,346,009$ & $9,974,174$ & 64,298 & $53,203,000$ \\
\hline \multicolumn{7}{|l|}{ Performance } \\
\hline Net income ${ }^{a}$ & 64 & 802,323 & 56,144 & $1,984,336$ & $-1,260,000$ & $9,004,000$ \\
\hline \multicolumn{7}{|c|}{ Panel B: Organizations' main industry } \\
\hline \multicolumn{2}{|c|}{ Industry } & $\mathrm{N}$ & \multicolumn{3}{|c|}{ Industry } & $\mathrm{N}$ \\
\hline \multicolumn{2}{|l|}{ Financial services/Insurance } & 15 & \multirow{2}{*}{\multicolumn{3}{|c|}{ Services }} & 4 \\
\hline \multicolumn{2}{|l|}{ Manufacturing } & 7 & & & & 3 \\
\hline \multicolumn{2}{|l|}{ Utilities } & 5 & \multicolumn{3}{|c|}{$\begin{array}{l}\text { Amusement } \\
\text { Retail/Wholesale }\end{array}$} & 9 \\
\hline \multicolumn{2}{|l|}{ Mining } & 4 & & 6 \\
\hline Oil \& Gas/Energy & & 11 & \multicolumn{3}{|c|}{ Telecommunications/Media } & \\
\hline \multicolumn{7}{|c|}{ Panel C: Respondents' number of years of professional experience } \\
\hline Number of years & $\mathrm{N}^{\mathrm{c}}$ & Mean & Median & Std Dev & Min. & Max. \\
\hline In total & 64 & 29.4 & 30.0 & 6.8 & 7 & 45 \\
\hline Within the organization & 62 & 10.8 & 7.5 & 9.6 & 1 & 40 \\
\hline In current position & 62 & 6.2 & 4.3 & 5.2 & 1 & 20 \\
\hline \multicolumn{7}{|c|}{ Panel D: Respondents' position and general background $(\mathrm{N}=64)$} \\
\hline \multicolumn{2}{|c|}{ Position within the organization } & $\mathrm{N}$ & \multicolumn{3}{|c|}{ Educational background } & $\mathrm{N}$ \\
\hline \multicolumn{2}{|l|}{ VP IT, VP IT \& Operations } & 13 & \multirow{2}{*}{\multicolumn{3}{|c|}{$\begin{array}{l}\text { IS/IT } \\
\text { Rusines/IT }\end{array}$}} & 36 \\
\hline \multicolumn{2}{|l|}{ VP IT \& CIO } & 4 & & & & 13 \\
\hline \multicolumn{2}{|l|}{$\mathrm{CIO}$} & 15 & \multicolumn{3}{|c|}{ Business/Accounting } & 8 \\
\hline \multicolumn{2}{|l|}{$\mathrm{CTO}$} & 2 & \multicolumn{3}{|c|}{$\begin{array}{l}\text { Engineering } \\
\text { Unsnecified }\end{array}$} & 2 \\
\hline \multicolumn{2}{|l|}{ IT Director } & 19 & \multicolumn{3}{|c|}{ Unspecified } & 5 \\
\hline IT Manager & & 5 & & & & \\
\hline $\mathrm{CEO}, \mathrm{COO}$ or $\mathrm{CFO}$ & & 5 & & & & \\
\hline VP Business solutions & & 1 & & & & \\
\hline
\end{tabular}

${ }^{a}$ Numbers are in thousands of Canadian dollars.

b The sample includes 50 companies listed on the Toronto Stock Exchange (TSX), and 14 governmental or paragovernmental organizations.

c Some respondents did not answer all the questions.

(e.g., Chun et al., 2014: 13.9\%; Lunardi et al., 2017: 22.3\%; Rivard et al., 2006: 13.7\%; Yeh et al., 2012: 19.1\%). Since information on executive management diversity was not available from public sources for three for-profit para-governmental organizations, the sample size is 64 .

The sample organizations' characteristics are set out in Table 1, Panels A and B. Almost $80 \%$ of the sample was comprised of listed firms; the remainder were for-profit para-governmental organizations. All the organizations were fairly large and, on average, profitable (Panel A). The industries most represented in the sample are Financial Services/Insurance, Oil \& Gas/Energy and Retail/Wholesale (Panel B). Table 1, Panels C and D, presents respondents' characteristics. On average, respondents had about six years of experience in their current position, more than 10 years within their organization, and 29 years in total (Panel C). Almost all respondents (over 92\%) held a position directly related to IT, while more than $75 \%$ had an educational background in IT (Panel D).

To lessen the concern for non-response bias, we performed analyses of variance comparing the group of respondents that answered the first mailing with the group that responded to later mailings 
(the latter being used as a proxy for the non-respondents). No significant differences were noted in the responses pertaining to IT governance constructs or the number of employees in total and in the IT function. Neither were any differences observed in terms of the organizations' assets, revenue, net income and market value. Thus, overall, the non-response bias does not seem to be a concern in this sample.

\section{Measurements}

\section{IT governance}

IT governance structures were measured using 27 items from De Haes and Van Grembergen (2009), Weill and Ross (2005), Ali and Green (2007), Parent and Reich (2009), and Bowen et al. (2007). ${ }^{5}$ We also included Yes/No questions to assess the presence of various committees and roles, such as the IT steering committee or the officer in charge of IT security, compliance and/or risk. IT governance processes were measured using 28 items from De Haes and Van Grembergen (2009), Weill and Ross (2005), and Bowen et al. (2007). IT governance relational mechanisms were measured using 21 items from Kearns and Lederer (2003) and De Haes and Van Grembergen (2009). As in Héroux and Fortin $(2013,2014)$, composite indexes were used to obtain an overall measure of IT governance structures, processes, relational mechanisms and overall IT governance (average of 28, 28, 21, and 76 items respectively). The items are presented in the tables set out in the results section. For all IT governance questions, the respondents were asked to indicate the degree to which they agreed with the item as it applied to their organization (strongly disagree $=1$, strongly agree $=7$ ). In light of Buchwald et al. (2014), our overall measure of IT governance captures the "extent to which a clearly defined and transparent set of structures, processes, and standards exists that is accepted throughout the organization and integrated into the daily work routines" (p. 143).

\section{Executive management diversity}

Similarly to Talke et al. (2010) and Boerner et al. (2011), we used Blau's (1977) formula ${ }^{6}$ to compute executive management diversity in terms of educational, functional and industry backgrounds. We measured executive management tenure diversity based on Allison's (1978) coefficient of variation ${ }^{7}$ (standard deviation/mean of the number of years each executive has been a member of the executive team). Educational background categories encompassed business administration, accounting, engineering, sciences, arts and humanities, law, and others. Functional background categories consisted of finance/accounting, marketing, human resources, production/ operations, research/development, information systems/IT, legal/general counsel, management, politics, communications/investor relations, strategy/development, and others. Industry background categories included financial services/insurance, manufacturing, mining, oil \& gas, retail/wholesale, telecommunications/IT/media, services, utilities, education, and government. Higher scores in terms of educational, functional and industry backgrounds and tenure were considered to indicate greater executive management diversity.

5 IT governance structures would normally include board-level structures (De Haes \& Van Grembergen, 2009). However, we exclude these structures since we focus on IT governance mechanisms that can be influenced by executive management.

6 Blau's (1977, p. 9) formula is $1-\left[\sum \mathrm{x}_{\mathrm{i}}^{2} /\left(\sum \mathrm{x}_{\mathrm{i}}\right)^{2}\right]$, where $\mathrm{x}_{\mathrm{i}}$ is the number of persons in each group, and the sum is taken over all groups. The closer the result of the calculation is to 1 , the greater the heterogeneity.

7 Since the coefficient of variation is a scale invariant measure, it is more appropriate than standard deviation or variance for interval scaled variables (Allison, 1978, in Boerner et al., 2011, p. 335). 


\section{Other contextual variables}

IT governance could be associated with IT intensity. For example, Parent and Reich (2009) point out that the most strategically offensive firms are the most IT intensive, whereas firms that use IT mainly for support purposes are the least IT intensive. Héroux and Fortin (2014) show that the degree of use of IT governance mechanisms is higher in firms in moderately and highly offensive IT mode than in firms in highly defensive IT mode. Five items derived from Brown and Magill (1994) were used to measure IT intensity. Respondents were asked to indicate the degree to which their organization's main operations are dependent on IT for the following five strategic choices: introducing new products; creating product differentiation; establishing competitive advantage; improving market access; and avoiding competitive disadvantage (not dependent $=1$, totally dependent $=7$ ).

IT governance may differ according to organization size. Firms with more revenues, assets and employees may tend to allocate more financial and human resources to the implementation of an effective IT governance system than smaller firms. In fact, many small and medium-sized firms have small internal IT groups (Huang et al., 2010) and fewer mature IT governance mechanisms than larger units (Thong, 1999). We measured size through the natural logarithm of total assets to normalize the distribution (Hair et al., 1998).

The industry environment moderates the relationship between executive management demographic characteristics and business strategy (Goll et al., 2008). Depending on the degree of managerial discretion allowed executive management in particular industries (Goll etal., 2008), industry sector could influence the design of IT governance, which is an element of the operationalization of business strategy. Organizations were classified into four industry groups (Financial services and Insurance; Manufacturing and Utilities; Oil \& Gas/Energy and Mining; Services, Amusement, Retail/ Wholesale and Telecommunications/Media organizations) to determine whether the clusters differed by industry.

\section{Descriptive statistics}

Descriptive statistics are presented in Table 2. For the 64 organizations overall, IT governance $($ mean $=4.35)$ is moderate, with processes and relational mechanisms moderately high $(\mathrm{mean}=4.64$ and 4.53 respectively) and structures moderate $($ mean $=3.92)\left(\right.$ Panel A). ${ }^{8}$ IT governance structures are thus less developed than processes and relational mechanisms. Furthermore, these organizations are moderately IT intensive (mean $=4.18$ ). Some organizations are quite large since the maximum value for Lnassets is more than twice the standard deviation. Table 2, Panel B provides an overview of IT governance structures. In $89 \%$ of the sample organizations, a senior executive/officer holds the IT governance function and $68 \%$ of these officers are members of the executive committee. Almost all organizations have an IT officer or manager responsible for IT security, compliance and/or risk (94\%). More than half have an IT steering committee at the executive level (59\%) and close to threequarters have an IT project steering committee (72\%). An IT security steering committee (41\%) and an IT architecture steering committee (34\%) are the least used structures.

Descriptive statistics on the demographic diversity characteristics are set out in Table 2, Panel C. With a value close to 1, functional diversity is the highest form of diversity, followed by educational diversity and then industry diversity. With the highest standard deviation, tenure diversity is expected to vary significantly between organizations.

8 Results around the mean are characterized as moderate (between 3.5 and 4.49). Mean results of 4.5 to 5.49 are characterized as moderate-high, high when 5.5 to 5.99 , and as very high when 6.0 and above. Mean results of 2.5 to 3.49 are characterized as low. Means below 2.5 are considered very low. 
Table 2. Descriptive statistics

\begin{tabular}{|c|c|c|c|c|c|c|c|}
\hline \multicolumn{8}{|c|}{ Panel A: Variables measured on a Likert-type scale $(\mathrm{N}=64)$} \\
\hline Variables & $\begin{array}{c}\mathrm{Nb} \text {. of } \\
\text { questions }\end{array}$ & $\begin{array}{c}\text { Cronbach } \\
\text { Alpha }\end{array}$ & Mean & Median & Std Dev. & Min. & Max. \\
\hline IT governance & 76 & 0.97 & 4.35 & 4.36 & 1.09 & 1.17 & 6.64 \\
\hline Structures & 27 & 0.95 & 3.92 & 4.24 & 1.62 & 1.00 & 6.41 \\
\hline Processes & 28 & 0.95 & 4.64 & 4.66 & 1.17 & 1.14 & 6.96 \\
\hline Relational mechanisms & 21 & 0.91 & 4.53 & 4.62 & 1.09 & 1.43 & 6.62 \\
\hline \multicolumn{8}{|l|}{ Other contextual variables } \\
\hline IT intensity & 5 & 0.89 & 4.18 & 4.40 & 1.54 & 1.00 & 7.00 \\
\hline Lnassets & - & - & 15.08 & 14.51 & 2.25 & 11.64 & 20.67 \\
\hline \multicolumn{8}{|c|}{ Panel B: Dichotomous variables } \\
\hline Variables & & & & & $\mathrm{N}$ & Yes & No \\
\hline \multicolumn{8}{|l|}{ IT governance structures } \\
\hline \multicolumn{5}{|c|}{ A senior executive (or officer) holds the IT governance function } & 64 & 57 & 7 \\
\hline \multicolumn{5}{|c|}{ If yes: $\mathrm{He} / \mathrm{She}$ is a member of the executive committee } & 57 & 39 & 18 \\
\hline \multicolumn{5}{|c|}{ An officer or a manager is responsible for IT security, compliance and/or risk } & 64 & 60 & 4 \\
\hline \multicolumn{5}{|c|}{ IT steering committee at the executive (or senior management) level } & 64 & 38 & 26 \\
\hline \multicolumn{5}{|c|}{ IT project steering committee } & 64 & 46 & 18 \\
\hline \multicolumn{5}{|c|}{ IT security steering committee } & 64 & 26 & 38 \\
\hline \multicolumn{5}{|c|}{ IT architecture steering committee } & 64 & 22 & 42 \\
\hline \multicolumn{8}{|c|}{ Panel C: Demographic diversity characteristics $(\mathrm{N}=64)$} \\
\hline \multicolumn{3}{|c|}{ Variables } & Mean & Median & Std Dev. & Min. & Max. \\
\hline \multicolumn{3}{|l|}{ Educational diversity } & 0.73 & 0.76 & 0.11 & 0.25 & 0.90 \\
\hline & 0.80 & 0.82 & 0.07 & 0.54 & 0.89 \\
\hline \multicolumn{3}{|l|}{$\begin{array}{l}\text { Functional diversity } \\
\text { Industry diversity }\end{array}$} & 0.65 & 0.67 & 0.14 & 0.22 & 0.85 \\
\hline \multicolumn{3}{|l|}{ Tenure diversity } & 0.60 & 0.59 & 0.23 & 0 & 1.06 \\
\hline
\end{tabular}

a Except Lnassets. The scale is from 1 to 7.

\section{Data analysis according to executive management demographic diversity profiles}

We used cluster analysis to classify the sample organizations into executive management diversity profiles. The main purpose of a cluster analysis "is to group objects based on the characteristics they possess [...] so that each object is very similar to others in the cluster with respect to some predetermined criterion" (Hair et al., 1998, p. 473). The criteria used to empirically classify our

data are the four demographic diversity variables. The potential number of groups was determined from a visual examination of dendrograms for a hierarchical cluster analysis using Ward's method. First, classification into three or four groups seemed to be appropriate. However, since one of the four groups was comprised of only eight organizations, three groups were determined as the optimal number of groups to be retained. Second, the analysis of agglomeration coefficients for hierarchical analysis confirmed that three groups led to a substantial increase in the value of agglomeration coefficients. The organizations were then classified into their respective groups in accordance with the correspondence table generated by the cluster analysis.

Descriptive data for the four diversity variables (mean values) are provided by group in Table 3 . ANOVAs indicate a significant difference between the mean educational and tenure diversity of Group 3 and that of Groups 1 and 2. Educational and tenure diversity are highest for Group 3 and thus characterize this group. ANOVAs show a significant difference between the mean industry and tenure 
diversity of Groups 1 and 2. Posting the highest industry diversity and lowest tenure diversity, Group 2 is thus characterized by these two attributes. Group 1 has the lowest mean for industry diversity and values close to the overall mean for educational and tenure diversity. However, Group 1's mean tenure diversity is significantly different from that of Groups 2 and 3 . We will therefore characterize Group 1 using the attributes of low industry diversity and moderate tenure. Since the ANOVA results for functional diversity indicate no significant differences between groups, this attribute is not used to characterize the groups.

Table 3. Analysis of group differences - demographic diversity characteristics

\begin{tabular}{|c|c|c|c|c|c|c|}
\hline \multirow[b]{2}{*}{ Variables } & \multicolumn{3}{|c|}{ Means } & \multicolumn{2}{|c|}{ Statistics } & \multirow{2}{*}{$\begin{array}{c}\text { Mean pairs with } \\
\text { significant differences }\end{array}$} \\
\hline & $\begin{array}{c}\mathrm{Gr} 1 \\
\mathrm{n}=35\end{array}$ & $\begin{array}{c}\mathrm{Gr} 2 \\
\mathrm{n}=11\end{array}$ & $\begin{array}{c}\text { Gr3 } \\
\mathrm{n}=18\end{array}$ & $\mathrm{~F}$ or $\mathrm{W}$ & & \\
\hline Educational diversity & 0.72 & 0.70 & 0.79 & $4.304 * *$ & & Gr1-3**; Gr2-3** \\
\hline Functional diversity & 0.80 & 0.77 & 0.82 & & 2.436 & - \\
\hline Industry diversity & 0.62 & 0.72 & 0.69 & $3.206^{* *}$ & & Gr1-2* \\
\hline Tenure diversity & 0.57 & 0.29 & 0.86 & $79.105 * * *$ & & $\begin{array}{c}\text { Gr1-2***; Gr1-3***; } \\
\text { Gr2-3*** }\end{array}$ \\
\hline
\end{tabular}

${ }^{a}$ If the variance is equal among groups according to the Levene Test, we examine the F Statistic; if not, the Welch Statistic. ${ }^{\mathrm{b}}$ Multiple comparisons between groups with the Tukey HSD Test (equal variance among groups; if not, Dunnett's T3 Test).

$\mathrm{c} * \mathrm{p} \leq 0.10 ; * * \mathrm{p} \leq 0.05 ; * * * \mathrm{p} \leq 0.01$.

ANOVAs were then used to assess whether the degree of use of IT governance mechanisms (overall, structures, processes and relational mechanisms) differed across executive management diversity profiles (Proposition 1). Between-group differences were also assessed in terms of contextual variables (IT intensity and size). Cross-tabulation and $\mathrm{Chi}^{2}$ were used to determine whether industry membership differed between groups.

ANOVAs were also used to determine whether the degree of use of specific IT governance mechanisms (structures, processes, relational mechanisms) differed across executive management diversity profiles (Proposition 2).

\section{RESULTS}

This exploratory study seeks evidence about the relationships between executive management diversity profiles and IT governance. In this section, we document the level of use of IT governance mechanisms by executive management diversity profiles and analyze between-group differences (Proposition 1). We then analyze specific IT governance mechanisms used under the different executive management diversity profiles (Proposition 2).

\section{Use of IT governance mechanisms according to executive management diversity profile (P1)}

Descriptive data for IT governance (mean values) are provided for the executive management diversity profiles (groups, hereafter Gr) in Table 4. ANOVAs indicate a significant difference between the mean of IT governance for the high educational-high tenure diversity profile (Gr3) and that of the 
low industry-moderate tenure diversity profile (Gr1) and the high industry-low tenure diversity profile (Gr2). In terms of structures, the only significant difference noted is between the high industry-low tenure profile (Gr2) and the high educational-high tenure diversity profile (Gr3). The former has a low mean for structures (3.17) while the latter has a moderate-high mean (4.66). However, for processes and relational mechanisms, a significant difference is observed between the low industry-moderate tenure diversity profile (Gr1) and the high educational-high tenure diversity profile (Gr3). The mean values for the latter profile (Gr3) are moderate-high, and moderate for the former (Gr1). These results provide evidence supporting Proposition 1; that is, that the degree of use of IT governance mechanisms differs according to executive management diversity profile.

Table 4. Analyses of between-group differences - IT governance and other contextual variables Demographic diversity groups according to cluster analysis

\begin{tabular}{|c|c|c|c|c|c|c|}
\hline \multirow{2}{*}{ Variables $^{\mathrm{a}}$} & \multicolumn{3}{|c|}{ Means $^{\mathrm{b}}$} & \multicolumn{2}{|c|}{ Statistics } & \multirow[b]{2}{*}{$\begin{array}{c}\text { Group pairs with } \\
\text { significant differences }\end{array}$} \\
\hline & $\begin{array}{c}\mathrm{Gr} 1 \\
\mathrm{n}=35\end{array}$ & $\begin{array}{c}\mathrm{Gr} 2 \\
\mathrm{n}=11\end{array}$ & $\begin{array}{c}\mathrm{Gr} 3 \\
\mathrm{n}=18\end{array}$ & $\mathrm{~F}$ or & Welch $^{c, d}$ & \\
\hline IT governance & 4.17 & 4.02 & 4.93 & $3.84 * *$ & & Gr1-3**; Gr2-3* \\
\hline Structures & 3.78 & 3.17 & 4.66 & $3.50 * *$ & & $\mathrm{Gr} 2-3 * *$ \\
\hline Processes & 4.39 & 4.65 & 5.12 & $2.43 *$ & & Gr1-3* \\
\hline Relational mechanisms & 4.36 & 4.27 & 5.01 & $5.73 *$ & & Gr1-3* \\
\hline \multicolumn{7}{|l|}{ Other contextual variables ${ }^{\mathrm{e}}$} \\
\hline IT intensity & 4.09 & 3.47 & 4.79 & & $4.48 * *$ & $\mathrm{Gr} 2-3 * *$ \\
\hline Lnassets & 14.60 & 14.87 & 16.13 & $3.01 *$ & & $\mathrm{Gr} 1-3 * *$ \\
\hline
\end{tabular}

a Variables measured on a Likert-type scale from 1 to 7 , except for Lnassets.

b Gr1=Low industry-moderate tenure diversity; Gr2=High industry-low tenure diversity; Gr3=High educational-high tenure diversity.

${ }^{c}$ If the variance is equal among groups according to the Levene Test, we examine the F Statistic; if not, the Welch Statistic. For multiple comparisons between groups, we use the Tukey HSD Test if variance is equal among groups; if not, we examine Dunnett's T3 Test.

$\mathrm{d} * * \mathrm{p} \leq 0.05 ; * \mathrm{p} \leq 0.10$.

e When classifying organizations into four industries (Financial services and Insurance; Manufacturing and Utilities; Oil\&Gas/Energy and Mining; and Services, Amusement, Retail/Wholesale and Telecommunications/Media organizations, $\mathrm{n}=15,12,15,22$ respectively), a cross tabulation of organizations' industry and cluster groups indicates no significant difference between groups according to industry membership.

For other contextual variables, we find that IT intensity differs significantly between the high industry-low tenure diversity profile (Gr2) and the high educational-high tenure diversity profile (Gr3), the latter group having the highest mean (4.79) and the former having the lowest (3.47). In terms of size, we observe a significant difference between the low industry-moderate tenure diversity profile (Gr1) and the high educational-high and tenure diversity profile (Gr3), which has the largest organizations. The cross-tabulation of organizations' industry and profiles (groups) indicates no significant difference between groups according to industry membership.

\section{Use of specific IT governance mechanisms according to executive management diversity profile (P2)}

In the following sections, we examine the significant differences between the means of the specific IT governance structures, processes and relational mechanisms to determine which are specific to a particular executive management diversity profile (i.e., used to different degrees depending on 
the diversity profile). We also indicate which IT governance structures, processes and relational mechanisms are used to a similar degree irrespective of the diversity profile.

\section{IT governance structures}

Table 5 shows several significant differences in respect of specific IT governance structures between the low industry-moderate tenure diversity profile (Gr1) and the high educational-high tenure diversity profile (Gr3). All these differences are in favor of the latter (Gr3), that is, the means are higher for this group. Moreover, these favorable differences all pertain to the IT steering committee, which is more involved in formulating the organization's IT strategies/policies, coordinating IT practices, providing leadership in deriving benefits from IT, and promoting IT strategic flexibility to meet the changing needs of the organization's internal and external environment.

Table 5. Analysis of demographic diversity group differences - IT governance structures

\begin{tabular}{|c|c|c|c|c|c|}
\hline \multirow[b]{2}{*}{ Variables $^{\mathrm{a}}$} & \multicolumn{3}{|c|}{ Means $^{b}$} & \multirow{2}{*}{$\begin{array}{c}\text { Statistics } \\
\text { F or Welch }{ }^{\mathrm{c}, \mathrm{e}}\end{array}$} & \multirow{2}{*}{$\begin{array}{l}\text { Mean pairs } \\
\text { with significant } \\
\text { differences }{ }^{\mathrm{d}, \mathrm{e}}\end{array}$} \\
\hline & $\begin{array}{c}\mathrm{Gr} 1 \\
\mathrm{n}=35\end{array}$ & $\begin{array}{c}\mathrm{Gr} 2 \\
\mathrm{n}=11\end{array}$ & $\begin{array}{l}\mathrm{Gr} 3 \\
\mathrm{n}=18\end{array}$ & & \\
\hline $\begin{array}{l}\text { 1. There is a senior executive (or officer) who is in } \\
\text { charge of IT governance. }\end{array}$ & 6.14 & 6.45 & 6.67 & 0.473 & --- \\
\hline $\begin{array}{l}\text { 2. The senior executive (or officer) in charge of IT } \\
\text { governance is a full member of the executive } \\
\text { committee. }\end{array}$ & 4.77 & 4.82 & 4.33 & 0.146 & --- \\
\hline
\end{tabular}

3. An officer or manager responsible for IT security, compliance and/or risk:
a) is responsible for developing and testing
5.29
5.45
6.00
0.872
privacy and security policies.
b) has sufficient authority to enforce privacy $\quad \begin{array}{llll}4.54 & 5.09 & 5.50 & 1.764\end{array}$ and security policies.
c) is responsible for assessing IT risks (e.g., impact on the business continuity).

$\begin{array}{llll}4.54 & 5.09 & 5.50 & 1.764 \\ 5.12 & 4.36 & 4.80\end{array}$
1.790
d) is responsible for managing changes resulting from IT projects.

$\begin{array}{llll}4.83 & 5.27 & 4.78 \quad 0.188\end{array}$
Mean $3 a$ to $3 d$
$5.08 \quad 5.45 \quad 5.65$
0.827

4. An IT steering committee at an executive (or senior management) level:
a) meets at least four times a year.
4.29
3.00
5.33
b) formulates the IT strategies/ policies of the
3.06
2.91
4.61
$2.644^{*}$
2.498 organization.
c) is involved in implementing the IT strategies/ policies.

$3.40 \quad 3.00 \quad 4.72$
4.72
2.36
4.83
$2.519 * *$
Gr2-3** priorities in IT investments.
e) provides strategic direction to IT projects.
3.57
2.45
$4.943 .536^{* *}$
Gr2-3**
f) coordinates IT practices.
2.40
2.18
3.78
$2.813^{*}$
Gr1-3*
g) provides leadership in deriving benefits from
2.86
2.82
$4.33 \quad 2.533^{*}$
Gr1-3* IT. 
Table 5. Cont.

\begin{tabular}{|c|c|c|c|c|c|}
\hline \multirow{2}{*}{ Variables $^{\mathrm{a}}$} & \multicolumn{3}{|c|}{ Means ${ }^{\mathrm{b}}$} & \multirow{2}{*}{$\begin{array}{c}\text { Statistics } \\
\text { F or Welch }{ }^{\mathrm{c}, \mathrm{e}}\end{array}$} & \multirow{2}{*}{$\begin{array}{c}\text { Mean pairs } \\
\text { with significant } \\
\text { differences }^{\mathrm{d}, \mathrm{e}}\end{array}$} \\
\hline & $\begin{array}{c}\mathrm{Gr} 1 \\
\mathrm{n}=35\end{array}$ & $\begin{array}{c}\mathrm{Gr} 2 \\
\mathrm{n}=11\end{array}$ & $\begin{array}{c}\text { Gr3 } \\
\mathrm{n}=18\end{array}$ & & \\
\hline $\begin{array}{l}\text { h) actively participates in the organization's IT } \\
\text { decision-making processes. }\end{array}$ & 3.29 & 2.91 & 4.78 & $2.591^{*}$ & --- \\
\hline $\begin{array}{l}\text { i) understands the business and the IT } \\
\text { objectives. }\end{array}$ & 3.69 & 2.82 & 4.83 & 2.352 & --- \\
\hline $\begin{array}{l}\text { j) makes IT investment decisions based on } \\
\text { business needs. }\end{array}$ & 3.83 & 2.45 & 5.17 & $3.773 * *$ & Gr2-3** \\
\hline $\begin{array}{l}\text { k) promotes IT strategic flexibility to meet the } \\
\text { changing needs of the organization's internal } \\
\text { and external environment. }\end{array}$ & 3.11 & 2.64 & 4.72 & $3.454^{*}$ & Gr1-3*; gr2-3* \\
\hline $\begin{array}{l}\text { 1) has business representatives with extensive IT } \\
\text { knowledge. }\end{array}$ & 2.66 & 1.45 & 3.28 & $6.192 * * *$ & $\begin{array}{l}\text { Gr1-2** } \\
\text { Gr2-3** }\end{array}$ \\
\hline $\begin{array}{l}\text { m) has IT representatives with extensive } \\
\text { business knowledge. }\end{array}$ & 3.57 & 2.73 & 4.33 & 1.696 & --- \\
\hline $\begin{array}{l}\text { n) has representatives from all major areas of } \\
\text { the organization. }\end{array}$ & 3.74 & 1.82 & 4.61 & $6.580 * * *$ & $\begin{array}{l}\text { Gr1-2**, } \\
\text { Gr2-3*** }\end{array}$ \\
\hline $\begin{array}{l}\text { o) has the most appropriate representatives from } \\
\text { each area. }\end{array}$ & 3.71 & 2.27 & 4.72 & $3.843 * *$ & Gr2-3** \\
\hline Mean 4 a to $4 o$ & 3.42 & 2.52 & 4.60 & $3.233 * *$ & Gr2-3** \\
\hline \multicolumn{6}{|l|}{ 5. An IT project steering committee: } \\
\hline a) is composed of business and IT people. & 5.09 & 3.91 & 4.61 & 0.815 & --- \\
\hline $\begin{array}{l}\text { b) focuses on prioritizing and managing IT } \\
\text { projects. }\end{array}$ & 4.69 & 4.55 & 4.33 & 0.109 & --- \\
\hline Mean $5 a$ and $5 b$ & 4.89 & 2.23 & 4.47 & 0.346 & --- \\
\hline \multicolumn{6}{|l|}{ 6. An IT security steering committee: } \\
\hline a) is composed of business and IT people. & 2.71 & 1.09 & 3.94 & $16.877 * * *$ & $\begin{array}{l}\text { Gr1-2***, } \\
\text { Gr2-3*** }\end{array}$ \\
\hline $\begin{array}{l}\text { b) focuses on IT-related risks and security } \\
\text { issues. }\end{array}$ & 2.94 & 2.09 & 4.50 & $3.236^{* *}$ & Gr2-3* \\
\hline Mean $6 a$ and $6 b$ & 2.83 & 1.59 & 4.22 & $7.067 * * *$ & Gr2-3*** \\
\hline \multicolumn{6}{|l|}{ 7. An IT architecture steering committee: } \\
\hline a) is composed of business and IT people. & 1.54 & 1.00 & 2.44 & $4.086^{* *}$ & $\begin{array}{l}\text { Gr1-2*; } \\
\text { Gr2-3*** }\end{array}$ \\
\hline $\begin{array}{l}\text { b) provides architecture guidelines and advice } \\
\text { on their applications. }\end{array}$ & 2.60 & 1.91 & 3.50 & 1.604 & --- \\
\hline Mean $7 a$ and $7 b$ & 2.07 & 1.45 & 2.97 & $3.418^{* *}$ & Gr2-3** \\
\hline
\end{tabular}

${ }^{a}$ Variables measured on a Likert-type scale from 1 to 7 , except for questions 1 and 2 for which No $=1$ and Yes $=7$.

${ }^{\mathrm{b}} \mathrm{Gr} 1=$ Low industry-moderate tenure diversity; Gr2=High industry-low tenure diversity; Gr3=High education-high tenure diversity.

${ }^{\mathrm{c}}$ If the variance is equal among groups according to the Levene Test, we examine the F Statistic; if not, the Welch Statistic. d Multiple comparisons between groups with the Tukey HSD Test (equal variance among groups; if not, Dunnett's T3 Test).

e $* * * \mathrm{p} \leq 0.01 ; * * \mathrm{p} \leq 0.05 ; * \mathrm{p} \leq 0.10$. 
We also note many significant differences in specific IT governance structures between the high industry-low tenure diversity profile (Gr2) and the high educational-high tenure diversity profile (Gr3), favoring the latter (Table 4). Gr2 organizations posted a lower level in relation to the following responsibilities and composition of the IT strategy committee: determining business priorities in IT investments; providing strategic direction to IT projects; making IT investment decisions based on business needs; promoting IT strategic flexibility to meet the changing needs of the organization's internal and external environment; having business representatives with extensive IT knowledge; having representatives from all major areas of the organization; and having the most appropriate representatives from each area. Also observed are significant differences between Gr2 and Gr3 for specific mechanisms pertaining to the IT security and IT architecture steering committees. Gr2 has very low means for the composition of both committees with business and IT people, as well as a low focus on IT-related risks and security issues.

Few significant differences are evident in terms of specific IT governance structures between the low industry-moderate tenure diversity profile ( $\mathrm{Gr} 1)$ and the high industry-low tenure diversity profile (Gr2) (Table 5). In comparison to Gr1, Gr2 has fewer business representatives with extensive IT knowledge and fewer representatives from all major areas of the organization on the IT steering committee. The composition of the IT security and IT architecture steering committees also differs, with Gr2 having a lower mean for the mix of business and IT people.

Table 4 also suggests that certain IT governance structures are used (or not extensively used) in all executive management diversity profiles. We can thus assume that these structures are used to similar degrees across diversity profiles. For example, in all three profiles, a senior executive (or officer) is often in charge of IT governance and in many cases this officer is an executive committee member. The responsibilities of the officer or manager in charge of IT security, compliance and/or risk are similar and can be situated at a moderate-high level in most cases, as can the characteristics of the IT project steering committee.

\section{IT governance processes}

Table 6 presents specific IT governance processes. Only a few differences can be seen between the means for the specific processes, and all but one are between the high educational-high tenure diversity profile (Gr3) and the low industry-moderate tenure diversity profile (Gr1). The differences are in favor of Gr3, which uses most of these processes at a high or very high level, in comparison to Gr1, which uses most of them at a moderate level. The specific processes are as follows: a formal planning process is used to update the IT strategy; the COSO (Committee of Sponsoring Organizations) or ERM (Enterprise Risk management) framework for internal control is used to govern IT; regular self-assessments or independent assurance activities on IT governance and control are performed; the organization regularly engages outside agencies to test its security systems or to conduct security audits; a prioritization process for IT investments and projects in which business and IT are involved is in place (e.g., business cases, return on investment); and IT strategies and policies define objectives and expectations, such as accountability and responsibility. The only difference between the high educational-high tenure diversity profile (Gr3) and the high industry-low tenure diversity profile (Gr2) is the moderate-high use by Gr3 of an IT governance and control framework (such as CobiT) to govern IT, in contrast to low use by Gr2. 
Table 6. Analysis of demographic diversity group differences - IT governance processes

\begin{tabular}{|c|c|c|c|c|c|c|}
\hline \multirow[b]{2}{*}{ Variables $^{\mathrm{a}}$} & \multicolumn{3}{|c|}{ Means $^{\mathrm{b}}$} & \multicolumn{2}{|c|}{ Statistics } & \multirow{2}{*}{$\begin{array}{l}\text { Mean pairs } \\
\text { with significant } \\
\text { differences }^{\mathrm{d}, \mathrm{e}}\end{array}$} \\
\hline & $\begin{array}{c}\mathrm{Gr} 1 \\
\mathrm{n}=35\end{array}$ & $\begin{array}{c}\mathrm{Gr} 2 \\
\mathrm{n}=11\end{array}$ & $\begin{array}{c}\mathrm{Gr} 3 \\
\mathrm{n}=18\end{array}$ & F or V & elch, e & \\
\hline \multicolumn{7}{|l|}{ GENERAL } \\
\hline $\begin{array}{l}\text { 1. A formal planning process is used to define the IT } \\
\text { strategy. }\end{array}$ & 4.55 & 4.91 & 5.61 & 2.152 & & - \\
\hline $\begin{array}{l}\text { 2. A formal planning process is used to update the IT } \\
\text { strategy. }\end{array}$ & 4.38 & 4.82 & 5.50 & $2.402 *$ & & Gr1-3* \\
\hline $\begin{array}{l}\text { 3. IT budgets are used to control and report on IT } \\
\text { activities/investments. }\end{array}$ & 5.12 & 5.36 & 6.00 & 2.099 & & - \\
\hline $\begin{array}{l}\text { 4. There are IT performance measures (e.g. } \\
\text { organization contribution, user orientation, } \\
\text { operational excellence or future orientation). }\end{array}$ & 3.72 & 4.55 & 4.78 & 2.029 & & - \\
\hline $\begin{array}{l}\text { 5. Methodologies are used to charge back IT costs to } \\
\text { business units. }\end{array}$ & 3.23 & 3.36 & 3.83 & 0.344 & & - \\
\hline $\begin{array}{l}\text { 6. There are formal agreements between business and } \\
\text { IT departments about IT development projects or IT } \\
\text { operations. }\end{array}$ & 3.72 & 3.91 & 4.72 & 1.201 & & - \\
\hline $\begin{array}{l}\text { 7. An IT governance and control framework } \\
\text { (such as CobiT) is used to govern IT. }\end{array}$ & 3.63 & 3.18 & 4.89 & $2.927^{*}$ & & Gr2-3* \\
\hline $\begin{array}{l}\text { 8. The COSO (Committee of Sponsoring } \\
\text { Organizations) or ERM (Enterprise Risk } \\
\text { Management) framework for internal control is used } \\
\text { to govern IT. }\end{array}$ & 2.83 & 3.36 & 4.50 & $3.712 * *$ & & Gr1-3** \\
\hline $\begin{array}{l}\text { 9. There are regular self-assessments or independent } \\
\text { assurance activities on IT governance and control. }\end{array}$ & 3.83 & 4.45 & 5.67 & & $5.958 * * *$ & Gr1-3*** \\
\hline $\begin{array}{l}\text { 10. The organization regularly engages outside } \\
\text { agencies to test its security systems or to conduct } \\
\text { security audits. }\end{array}$ & 4.38 & 5.09 & 6.00 & & $5.377 * * *$ & Gr1-3*** \\
\hline \multicolumn{7}{|l|}{$\begin{array}{l}\text { EVALUATION, SELECTION AND MANAGEMENT OF IT } \\
\text { PROJECTS }\end{array}$} \\
\hline $\begin{array}{l}\text { 11. There is a prioritization process for IT investments } \\
\text { and projects in which business and IT are involved } \\
\text { (e.g. business cases, return on investment). }\end{array}$ & 5.18 & 5.55 & 6.17 & & $3.882 * *$ & Gr1-3** \\
\hline $\begin{array}{l}\text { 12. Explicit criteria are used to help evaluate IT } \\
\text { projects. }\end{array}$ & 4.73 & 4.82 & 5.08 & & 0.297 & - \\
\hline $\begin{array}{l}\text { 13. Both qualitative and quantitative criteria are used } \\
\text { to evaluate IT projects. }\end{array}$ & 5.10 & 5.18 & 5.67 & 0.733 & & - \\
\hline $\begin{array}{l}\text { 14. A cost/benefit analysis is used to evaluate IT } \\
\text { projects. }\end{array}$ & 4.58 & 5.45 & 5.28 & & 1.748 & - \\
\hline $\begin{array}{l}\text { 15. Project cost data are fully identified (direct, } \\
\text { indirect, ongoing). }\end{array}$ & 4.90 & 5.18 & 5.61 & & 1.153 & - \\
\hline $\begin{array}{l}\text { 16. IT investment benefits are identified using } \\
\text { quantitative and/or qualitative data that relate } \\
\text { directly to business strategies and performance } \\
\text { improvement (tracking IT business value). }\end{array}$ & 4.73 & 4.00 & 4.39 & & 0.904 & - \\
\hline
\end{tabular}


Table 6. Cont.

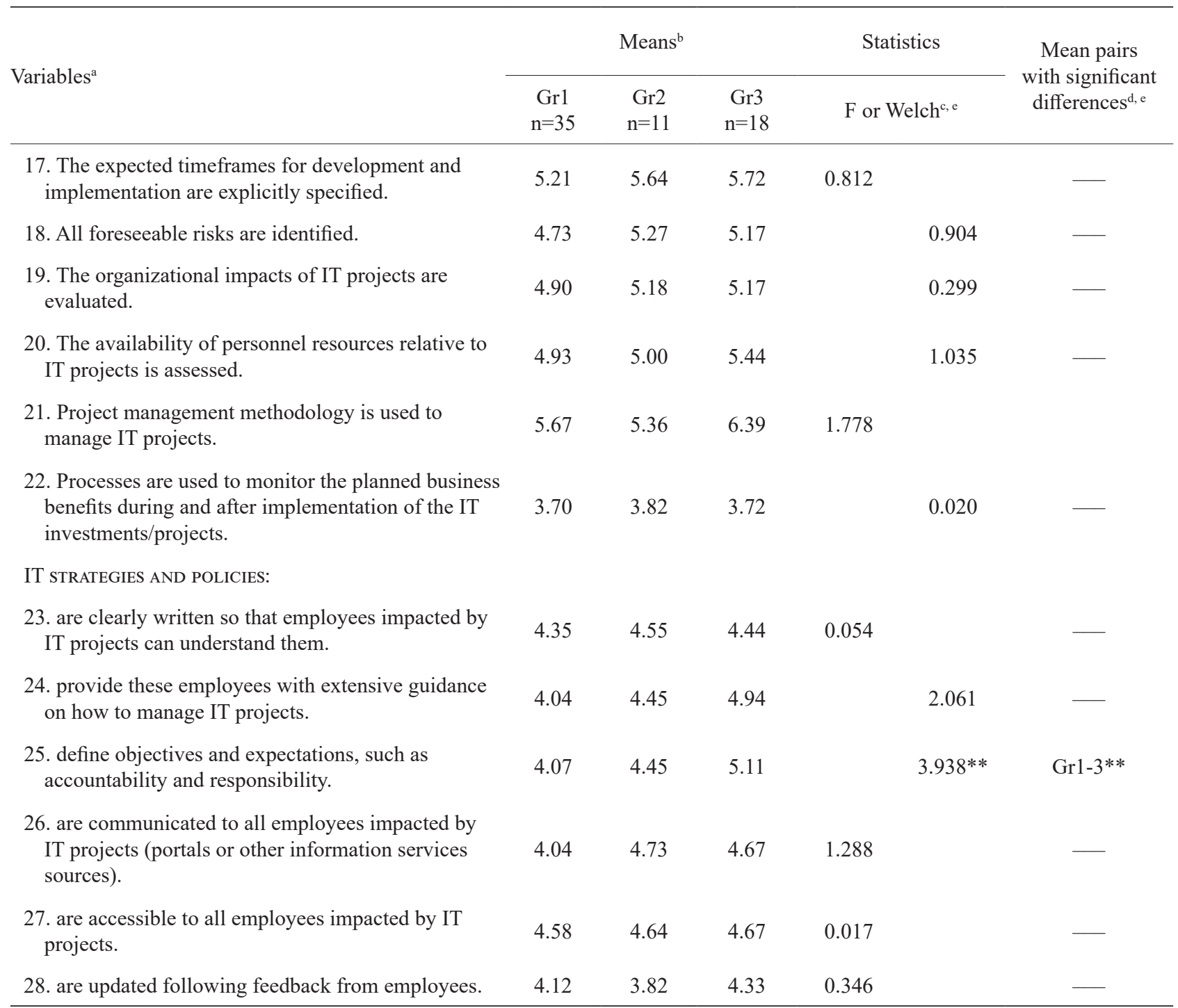

a Variables measured on a Likert-type scale from 1 to 7.

b Gr1=Low industry-moderate tenure diversity; Gr2=High industry-low tenure diversity; Gr3=High education-high tenure diversity.

c, If the variance is equal among groups according to the Levene Test, we examine the F Statistic; if not, the Welch Statistic.

d Multiple comparisons between groups with the Tukey HSD Test (equal variance among groups; if not, Dunnett's T3 Test).

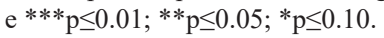

The most notable IT governance processes that are used to a moderate-high or higher level in all executive management diversity profiles are: the use of a formal planning process to define the IT strategy; the use of IT budgets to control and report on IT activities/investments; and the use of many IT project related mechanisms (namely, the use of explicit criteria, both qualitative and quantitative, to help evaluate IT projects, as well as a cost-benefit analysis, the full identification of cost data and all foreseeable risks, the explicit specification of expected timeframes for development and implementation of IT projects, the evaluation of their organizational impacts, the assessment of the availability of human resources, the use of project management methodology, and the accessibility of IT strategies and policies to all employees impacted by IT projects). 


\section{IT governance relational mechanisms}

In Table 7, which sets outs specific relational mechanisms, significant differences between profiles are noted for only two. Senior business and IT management act as partners to a greater extent in the high educational-high tenure diversity profile (Gr3) than in the low industry-moderate tenure

Table 7. Analysis of demographic diversity group differences - IT governance relational mechanisms

\begin{tabular}{|c|c|c|c|c|c|}
\hline \multirow[b]{2}{*}{ Variables $^{\mathrm{a}}$} & \multicolumn{3}{|c|}{ Means $^{\mathrm{b}}$} & Statistics & \multirow{2}{*}{$\begin{array}{l}\text { Mean pairs } \\
\text { with significant } \\
\text { differences }{ }^{\mathrm{d}} \\
(* * \mathrm{p} \leq 0.05)\end{array}$} \\
\hline & $\begin{array}{c}\mathrm{Gr} 1 \\
\mathrm{n}=35\end{array}$ & $\begin{array}{c}\mathrm{Gr} 2 \\
\mathrm{n}=11\end{array}$ & $\begin{array}{c}\mathrm{Gr} 3 \\
\mathrm{n}=18\end{array}$ & $\begin{array}{c}\mathrm{F} \quad \text { or } \quad \mathrm{Welch}^{\mathrm{c}} \\
(* * * \mathrm{p} \leq 0.01 ; * \mathrm{p} \leq 0.10)\end{array}$ & \\
\hline $\begin{array}{l}\text { 1. The senior executive/officer in charge of } \\
\text { IT articulates a vision for IT's role in the } \\
\text { organization. }\end{array}$ & 5.43 & 5.36 & 5.78 & 0.366 & --- \\
\hline $\begin{array}{l}\text { 2. The senior executive/officer in charge of IT } \\
\text { ensures that the vision for IT's role is clearly } \\
\text { understood by managers throughout the } \\
\text { organization. }\end{array}$ & 4.91 & 4.91 & 5.56 & 1.313 & --- \\
\hline $\begin{array}{l}\text { 3. Business / administrative managers act as in- } \\
\text { between business and IT. }\end{array}$ & 3.90 & 3.82 & 4.61 & 0.904 & --- \\
\hline $\begin{array}{l}\text { 4. Senior business and IT management act as } \\
\text { "partners." }\end{array}$ & 4.96 & 4.82 & 5.89 & $5.669 * * *$ & Gr1-3**; Gr2-3** \\
\hline $\begin{array}{l}\text { 5. Senior business and IT management } \\
\text { informally discuss the organization's activities } \\
\text { and IT's role }\end{array}$ & 5.39 & 5.45 & 5.61 & 0.202 & --- \\
\hline $\begin{array}{l}\text { 6. There is job rotation (IT staff working in the } \\
\text { business units and business people working in } \\
\text { IT). }\end{array}$ & 1.99 & 2.09 & 2.61 & 1.138 & --- \\
\hline $\begin{array}{l}\text { 7. Business and IT people are physically located } \\
\text { close to each other. }\end{array}$ & 4.83 & 4.36 & 5.17 & 0.733 & --- \\
\hline $\begin{array}{l}\text { 8. Business people are trained in IT or IT people } \\
\text { are trained in business. }\end{array}$ & 3.53 & 3.82 & 3.89 & 0.359 & --- \\
\hline $\begin{array}{l}\text { 9. Systems such as Intranet are used to share and } \\
\text { distribute knowledge about the IT governance } \\
\text { framework, responsibilities, tasks, etc. }\end{array}$ & 4.26 & 4.18 & 5.44 & 2.274 & --- \\
\hline $\begin{array}{l}\text { 10. Internal corporate communication regularly } \\
\text { addresses general IT issues. }\end{array}$ & 3.91 & 3.82 & 4.17 & 0.1657 & --- \\
\hline $\begin{array}{l}\text { 11. There are campaigns explaining the need for } \\
\text { IT governance to business and IT people. }\end{array}$ & 2.74 & 2.73 & 3.72 & 2.002 & --- \\
\hline \multicolumn{6}{|l|}{ THE IT EXECUTIVE OR SENIOR MANAGER: } \\
\hline 12. regularly attends business planning & 5.03 & 5.09 & 5.89 & 1.073 & --- \\
\hline $\begin{array}{l}\text { 13. contributes to the formulation of business } \\
\text { goals. }\end{array}$ & 4.77 & 4.64 & 5.61 & 1.150 & --- \\
\hline $\begin{array}{l}\text { 14. has regular informal contacts with executive } \\
\text { management. }\end{array}$ & 5.86 & 5.82 & 6.33 & 0.742 & --- \\
\hline 15. has easy access to the CEO. & 5.66 & 5.55 & 6.11 & 0.420 & --- \\
\hline 16. has frequent contacts with the CEO. & 5.06 & 5.18 & 6.00 & 1.1414 & --- \\
\hline
\end{tabular}


Table 7. Cont.

\begin{tabular}{|c|c|c|c|c|c|c|}
\hline \multirow{2}{*}{ Variables $^{\mathrm{a}}$} & \multicolumn{3}{|c|}{ Means ${ }^{\mathrm{b}}$} & \multicolumn{2}{|c|}{ Statistics } & \multirow{2}{*}{$\begin{array}{c}\text { Mean pairs } \\
\text { with significan } \\
\text { differences }^{\mathrm{d}} \\
(* * \mathrm{p} \leq 0.05)\end{array}$} \\
\hline & $\begin{array}{c}\mathrm{Gr} 1 \\
\mathrm{n}=35\end{array}$ & $\begin{array}{c}\mathrm{Gr} 2 \\
\mathrm{n}=11\end{array}$ & $\begin{array}{c}\mathrm{Gr} 3 \\
\mathrm{n}=18\end{array}$ & $\begin{array}{c}\mathrm{F} \quad \text { or } \\
(* * * \mathrm{p} \leq 0.01 ; *\end{array}$ & $\begin{array}{l}\text { Welch } \\
* \mathrm{p} \leq 0.10)\end{array}$ & \\
\hline \multicolumn{7}{|l|}{ THE CEO: } \\
\hline $\begin{array}{l}\text { 17. plays an important role in the IT steering } \\
\text { committee. }\end{array}$ & 3.31 & 3.36 & 3.83 & & 0.311 & --- \\
\hline $\begin{array}{l}\text { 18. becomes knowledgeable about competitors' } \\
\text { use of IT. }\end{array}$ & 3.29 & 3.09 & 4.22 & & 1.475 & --- \\
\hline $\begin{array}{l}\text { 19. has frequent informal contacts with IT } \\
\text { management. }\end{array}$ & 4.40 & 4.09 & 4.61 & 0.203 & & --- \\
\hline $\begin{array}{l}\text { 20. becomes knowledgeable about IT } \\
\text { opportunities within the firm. }\end{array}$ & $3+94$ & 3.91 & 4.78 & 1.080 & & --- \\
\hline $\begin{array}{l}\text { 21. regards spending on IT as strategic } \\
\text { investments rather than expenses to be } \\
\text { controlled. }\end{array}$ & 4.40 & 3.55 & 5.33 & $3.097 *$ & & Gr2-3** \\
\hline
\end{tabular}

a Variables measured on a Likert-type scale from 1 to 7.

b Gr1=Low industry-moderate tenure diversity; Gr2=High industry-low tenure diversity; Gr3=High education-high tenure diversity.

c If the variance is equal among groups according to the Levene Test, we examine the F Statistic; if not, the Welch Statistic.

d Multiple comparisons between groups with the Tukey HSD Test (equal variance among groups; if not, Dunnett's T3 Test).

diversity profile (Gr1) or in the high industry-low tenure diversity profile (Gr2). In comparison to the latter, the CEO in the high educational-high tenure diversity profile (Gr3) is more inclined to consider IT spending as strategic investments than as expenses to be controlled.

The following IT governance relational mechanisms are used to a moderate-high or higher level in all executive management diversity profiles: the senior executive/officer in charge of IT articulates a vision for IT's role in the organization and ensures that this vision is clearly understood by managers throughout the organization; senior business and IT management informally discuss the organization's activities and IT's role; and the IT executive or senior manager regularly attends business planning meetings, contributes to the formulation of business goals, has regular informal contacts with executive management, has easy access to the CEO and frequent contacts with him/ her. However, most relational mechanisms pertaining to the CEO are used moderately or less by all diversity profiles.

In all, the above results provide some support for Proposition 2 since the degree of use of certain IT governance structures, processes and relational capabilities differs according to executive management diversity profile. A wider variation is noted in the degree to which IT governance structures are used than in the degree of use of IT governance processes or relational mechanisms. More specifically, IT governance structures differ according to executive management diversity profile more than IT governance processes or relational mechanisms. Those structures that differ according to executive management diversity profile are mainly tied to the role and/or composition of the IT steering committee, the IT security steering committee and the IT architecture steering committee.

Table 8 provides an overview of the degree of use of IT governance structures, processes and relational and specific mechanisms for which significant differences are observed between 
demographic diversity profiles, as well as other attributes. For specific structures, rather than focusing on the individual questions within structures, the table presents structures (based on the means of their related questions in Table 5) irrespective of whether there are significant differences between profiles. Table 8 was developed by characterizing the means set out in Tables 4 to 7 using the scale presented in footnote number 8 .

Table 8. Overview - Degree of use of IT governance mechanisms and other attributes according to demographic diversity profiles

\begin{tabular}{|c|c|c|c|}
\hline \multirow[b]{2}{*}{ Attributes } & \multicolumn{3}{|c|}{ Demographic diversity profiles } \\
\hline & $\begin{array}{l}\text { Low industry-moderate } \\
\text { tenure }\end{array}$ & $\begin{array}{l}\text { High industry- } \\
\text { low tenure }\end{array}$ & $\begin{array}{l}\text { High education-high } \\
\text { tenure }\end{array}$ \\
\hline \multicolumn{4}{|l|}{ Degree of use of IT governance mechanisms } \\
\hline Structures & Moderate & Low & Moderate-High \\
\hline Processes & Moderate & Moderate-High & Moderate-High \\
\hline Relational mechanisms & Moderate & Moderate & Moderate-High \\
\hline Overall & Moderate & Moderate & Moderate-High \\
\hline \multicolumn{4}{|l|}{ Specific structures: } \\
\hline $\begin{array}{l}\text { Officer/manager responsible for IT security, compliance } \\
\text { and/or risk }\end{array}$ & Moderate-High & Moderate-High & High \\
\hline $\begin{array}{l}\text { IT steering committee at an executive/senior management } \\
\text { level }\end{array}$ & Low & Low & Moderate-High \\
\hline IT project steering committee & Moderate-High & Moderate & Moderate \\
\hline IT security steering committee & Low & Very low & Moderate \\
\hline IT architecture steering committee & Very low & Very low & Low \\
\hline \multicolumn{4}{|l|}{ Specific processes: } \\
\hline $\begin{array}{l}\text { A formal planning process is used to update the IT } \\
\text { strategy. }\end{array}$ & Moderate & Moderate-High & High \\
\hline $\begin{array}{l}\text { An IT governance and control framework (such as CobiT) } \\
\text { is used to govern IT. }\end{array}$ & Moderate & Low & Moderate-High \\
\hline $\begin{array}{l}\text { The COSO (Committee of Sponsoring Organizations) } \\
\text { or ERM (Enterprise Risk Management) framework for } \\
\text { internal control is used to govern IT. }\end{array}$ & Low & Low & Moderate-High \\
\hline $\begin{array}{l}\text { There are regular self-assessments or independent } \\
\text { assurance activities on IT governance and control. }\end{array}$ & Moderate & Moderate & High \\
\hline $\begin{array}{l}\text { Outside agencies are regularly hired to test the } \\
\text { organization's security systems or to conduct security } \\
\text { audits. }\end{array}$ & Moderate & Moderate-High & Very high \\
\hline $\begin{array}{l}\text { There is a prioritization process for IT investments and } \\
\text { projects in which business and IT are involved (e.g. } \\
\text { business cases, return on investment). }\end{array}$ & Moderate-High & High & Very high \\
\hline $\begin{array}{l}\text { IT strategies and policies define objectives and } \\
\text { expectations, such as accountability and responsibility. }\end{array}$ & Moderate & Moderate & Moderate-High \\
\hline \multicolumn{4}{|l|}{ Specific relational mechanisms: } \\
\hline Senior business and IT management act as "partners." & Moderate-High & Moderate-High & High \\
\hline $\begin{array}{l}\text { The CEO regards spending on IT as strategic investments } \\
\text { rather than expenses to be controlled. }\end{array}$ & Moderate & Moderate & Moderate-High \\
\hline \multicolumn{4}{|l|}{ Other attributes } \\
\hline IT intensity & Moderate & Low & Moderate-High \\
\hline Size (Lnassets) & Medium-Large & Medium-Large & Large \\
\hline
\end{tabular}




\section{DISCUSSION}

The objective of this study was to explore the relationship between the degree of use of IT governance mechanisms (structures, processes, relational mechanisms) and executive management diversity profiles (based on functional, industry and educational backgrounds and tenure). Our results suggest that IT governance for the high educational-high tenure diversity profile differs significantly from that for the low industry-moderate tenure diversity profile and the high industry-low tenure diversity profile. Furthermore, IT governance structures differ by executive management diversity profile more than IT governance processes or relational mechanisms. These findings support Pelled (1996) as they suggest that different types of diversity produce different outcomes. However, it appears that diversity in executive management experience gained from functional background does not distinguish profiles from each other. In other words, diversity in functional background is similar between firms. This appears to be plausible since it is common to find executives with many different functional backgrounds (IT and non-IT) in medium-large firms' executive management.

On the whole, in large firms with moderate-high IT intensity, high diversity in educational background and tenure among executive management appears to be a "good mix" for greater use of IT governance structures, processes and relational mechanisms. This suggests that diversity in the disciplines in which executives have studied, combined with differences in executives' tenure, could help build IT governance knowledge and enhance IT governance mechanisms as a whole. It is plausible to assume that these large-IT intensive firms are particularly confronted with uncertain situations as IT is constantly evolving. The high diversity in their executive management could lead to conflicts and disagreements. However, as suggested by Eisenhardt et al. (1997), diversity can broaden executive management's range of viewpoints. Despite potential conflict between executives, these firms seem to overcome IT governance-related conflicts and disagreements resulting from diversity. In fact, as suggested by (Tallon, 2014), even if all executives may not be in complete agreement, it becomes crucial for these firms to reach a consensus in terms of IT-related strategic decision making. The greater degree of use of IT governance mechanisms appears to be an example of such consensus.

In medium-large organizations that are less IT-intensive (i.e., with low or moderate IT intensity), two executive management demographic diversity profiles emerge from our data: high industry-low tenure and low industry-moderate tenure. Organizations from both profiles use IT governance to a lesser extent than large IT-intensive firms with a high education-high tenure profile. This tendency could be because there is less need in these firms to develop IT governance mechanisms compared to larger firms with moderate-high IT intensity.

More specifically, when executive management is characterized by high industry-low tenure diversity, some IT governance structures seem to be used to a lesser extent and some IT governance processes appear to be more developed than when it is characterized by low industry-moderate tenure. In fact, diversity in tenure seems to enhance IT governance structures, while diversity in industry background appears to increase the use of IT governance processes. In short, in medium-large organizations that are less IT-intensive (i.e., with low or moderate IT intensity), when the dominant diversity attribute is industry background (high industry), we found more developed IT governance processes. In contrast, there is a greater use of some IT governance structures when tenure diversity is the dominant attribute (moderate tenure). Having executive management with less diverse tenure could limit the extent and types of discussions that would lead to the use of more sophisticated IT governance structures such as IT project or IT security steering committees. Furthermore, executive 
management with greater diversity in industry background could have executives that "push for" the development of specific IT governance processes, such as a formal planning process to update IT strategy and hiring outside agencies to test the organization's security systems or conduct security audits.

\section{CONCLUSION, RESEARCH AVENUES AND LIMITATIONS}

In this exploratory study, we tried to capture different facets of diversity in a "diversity profile" as we explored their impact on a set of IT governance mechanisms. Our empirical results provide insights into the potential influence of different mixes of demographic diversity in executive management on the use of IT governance mechanisms. Organizations could determine which of these profiles suits them best in light of their IT governance needs. A mix of high education and high tenure diversity would seem to be favorable to the development of organizations seeking to improve their IT governance. Overall, our results could make organizations more aware of the influence of executive management diversity and provide them with new ideas in terms of IT governance structures, processes and relational mechanisms.

Based on the upper echelon theory and related literature on executive management demographics and demographic diversity, this study extends IT governance literature. More specifically, it complements results from prior studies on group-specific antecedents of IT governance. It also adds to literature on the consequences of diversity in an IT context. Results suggest that different types of executive management diversity "produce" different IT governance mechanisms. To enhance our understanding of how this happens, future research based on interviews with executives could be relevant. Since executive management can change over time, diversity is expected to change as well. Therefore, it could also be relevant to examine the impact of a change in diversity on IT governance over time.

Executive management diversity can lead to both consensus and conflict. Future research could investigate whether different types of diversity engender more (or less) consensus or conflict. Studies could also examine whether consensus/conflict acts as a mediating or moderating variable between types of demographic diversity and IT governance mechanisms.

As with any study, this paper has some limitations. Given the exploratory nature of the study, the small sample size was acceptable. However, a larger sample in future research would support the generalizability of the findings. Since the data on IT governance were obtained through the administration of questionnaires, the usual limitations pertaining to surveys apply. Notably, a social desirability bias may have prompted participants to overstate their answers on the response scales. The assessment of demographic characteristics was dependent on the information available from Boardex and public sources that may not have been exhaustive.

\section{ACKNOWLEDGMENTS}

We would like to acknowledge the financial support of the Canadian Academic Accounting Association Research Grant Program and the Autorité des marchés financiers/Corporate Reporting Chair of ESG-UQAM. 


\section{REFERENCES}

Agnihotri, A. (2014). The role of the upper echelon in the value chain management. Competitiveness Review, $24(3), 240-255$.

Ali, S., \& Green, P. (2007). IT governance mechanisms in public sector organizations: An Australian context. Journal of Global Information Management, 15(4), 41-63.

Ali, S., Green, P., \& Robb, A. (2013). Measuring top management's IT governance knowledge absorptive capacity. Journal of Information Systems, 27(1), 137-155.

Allison, P. (1978). Measures of inequality. American Sociological Review, 43(6), 865-880.

Awino, Z. B. (2013). Top management team diversity, quality decisions and organizational performance in the service industry. Journal of Management and Strategy, 4(1), 113-123.

Balta, M. E., Woods, A., \& Dickson, K. (2013). Strategic decision-making processes as a mediator of the effect of board characteristics on company innovation: A study of publicly-listed firms in Greece. International Journal of Management, 30(1), 311-328.

Bantel, K., \& Jackson, S. (1989). Top management and innovations in banking: Does the composition of the top team make a difference? Strategic Management Journal, 10(summer), 107-124.

Barker III, V. L., (2002) Mueller, G. C. (2002). CEO characteristics and firm R\&D spending. Management Science, 48(6), 782-801.

Blaskovich, J., \& Mintchik, N. (2011). Accounting executives and IT outsourcing recommendations: An experimental study on the effect of CIO skills and institutional isomorphism. Journal of Information Technology, 26(2), 139-152.

Blau, P. M. (1977). Inequality and heterogeneity: a primitive theory of social structure. Collier Macmillan Publishers, London.

Boerner, S., Linkohr, M., \& Kiefer, S. (2011). Top management team diversity: Positive in the short run, but negative in the long run? Team Performance Management, 17(7/8), 328-353.

Boone, C., \& Hendriks, W. (2009). Top management team diversity and firm performance: Moderators of functional-background and locus-of-control diversity. Management Science, 55(2), 165-180.

Bowen, P. L., Cheung, M-Y. D., \& Rohde, F. H. (2007). Enhancing IT governance practices: A model and case study of an organization's efforts. International Journal of Accounting Information Systems, 8, 191221.

Bradley, R., Byrd, T. A., Pridmore, J. L., Trasher, E., Pratt, R. ME., \& Mbarika, V. WA. (2012). An empirical examination of antecedents and consequences of IT governance in US hospitals. Journal of Information Technology, 27, 156-177.

Brown, A. E., \& Grant, G. G. (2005). Framing the frameworks: a review of IT governance research. Communications of the Association for Information Systems, 15, 696-712.

Brown, C. V., \& Magill, S. L. (1994). Alignment of the IS functions with the enterprise: Toward a model of antecedents. MIS Quarterly, 14(4), 371-404.

Bruque, S., \& Moyano, J. (2007). Organizational determinants of information technology adoption and implementation in SMEs: The case of family and cooperative firms. Technovation, 27(5), 241-253.

Bruque-Camara, S., Vargas-Sanchez, A, \& Hernandez-Ortiz, M. J. (2004). Organizational determinants of IT adoption in the pharmaceutical distribution sector. European Journal of Information Systems, 13(2), 133146. 
Bushwald, A., Urbach, N., \& Ahlemann, F. (2014). Business value through controlled IT: Toward an integrated model of IT governance success and its impact. Journal of Information Technology, 29, 128147.

Carpenter, M. A., Geletkanycz, M. A., \& Sanders, W. G. (2004). Upper echelons research revisited: Antecedents, elements, and consequences of top management composition. Journal of Management, 30(6), 749-778.

Chun, M. W. S., Griffy-Brown, C., \& Koeppel, H. (2014). The new normal: Fundamental shifts for 21th century organizations and for the CIOs who lead them. Journal of Applied Business and Economics, 16(5), 27-49.

Colombelli, A. (2015). Top management team characteristics and firm growth. International Journal of Entrepreneurial Behavior \& Research, 21(1), 107-127.

De Haes, S., \& Van Grembergen, W. (2009). An exploratory study into IT governance implementation and its impact on business / IT alignment. Information Systems Management, 26(2), 123-137.

De Haes, S., \& Van Grembergen, W. (2013). Improving enterprise governance of IT in a major airline: A teaching case. Journal of Information Technology Teaching Cases, 3, 60-69.

Dillman, D. A. (2000). Mail and Internet Surveys: The Tailored Design Method (2nd ed.). New York, John Wiley and Sons.

Eisenhardt, K. M., Kahwajy, J. L., \& Bourgeois III, L. J. (1997). Conflict and strategic choice: How top management teams disagree. California Management Review, 39(2), 42-62.

Finkelstein, S., and Hambrick, D. C. (1990). Top management team tenure and organizational outcomes: The moderating role of managerial discretion. Administrative Science Quarterly, 35(3), 484-503.

Goll, I., Brown Johnson, N., \& Rasheed, A. A. (2008). Top management team demographic characteristics, business strategy, and firm performance in the US airline industry. Management Decision, 46(2), 201-222.

Hair, J. F., Anderson, R. E., Tatham, R. L., \& Black, W. C. (1999). Multivariate Data Analysis (5th ed.). Upper Saddle River, NJ: Prentice Hall.

Hambrick, D.C. \& Finkelstein, S. (1987). Managerial discretion: A bridge between polar views of organizational outcomes. Research in Organizational Behavior, 9, 369-406.

Hambrick, D., \& Mason, P. (1984). Upper echelon: The organization as a reflection of its top managers. Academy of Management Review, 9(1), 193-206.

Heart, T., Maoz, H, \& Pliskin, N. (2010). From governance to adaptability: The mediating effect of IT executives’ managerial capabilities. Information Systems Management, 27(1), 42-60.

Henderson, A. D., Miller, D., \& Hambrick, D. C. (2006). How quickly do CEOs become obsolete? Industry dynamism, CEO tenure, and company performance. Strategic Management Journal, 27(5), 447-460.

Hendrickson, G., \& Santos, C. D. Jr. (2014). Information technology governance in public organizations: How perceived effectiveness relates to three classical mechanisms. Journal of Information Systems and Technology Management, 11(2), 297-326.

Héroux, S., \& Fortin, A. (2014). Exploring IT Dependence and IT Governance. Information Systems Management, 31(2), 143-166.

Héroux, S., \& Fortin, A. (2013). The Internal Audit Function in Information Technology Governance: A Holistic Perspective. Journal of Information Systems, 27(1), 189-217.

Huang, R., Zmud, R. W., \& Price, R. L. (2010). Influencing the effect of IT governance practices through steering committees and communication policies. European Journal of Information Systems, 19(3), 288302. 
ITGI (IT Governance Institute). (2003). Board Briefing on IT Governance (2nd ed.). Rolling Meadows, Illinois: IT Governance Institute. Retrieved from http://www.isaca.org/restricted/Documents/26904 Board_Briefing_final.pdf

Jeyaraj, A., Rottman, J. W., \& Lacity, M. C. (2006). A review of the predictors, linkages, and biases in IT innovation adoption research. Journal of Information Technology, 21(1), 1-23.

Karanja, E., \& Zaveri, J. (2012). IT leaders: Who are they and where do they come from? Journal of Information Systems Education, 23(2), 143-163.

Kearns, G., \& Lederer, A. L. (2003). A resource-based view of strategic IT-alignment: How knowledge sharing creates competitive advantage. Decision Sciences, 34(1), 1-29.

Knight, D., Pearce, C. L., Smith, K. G., Olian, J. D., Sims, H. P., Smith, K. A., \& Flood, P. (1999). Top management team diversity, group process, and strategic consensus. Strategic Management Journal, $20(5), 445-465$.

Li, C-R. (2013). How top management team diversity fosters organizational ambidexterity: The role of social capital among top executives. Journal of Organizational Change Management, 26(5), 874-896.

Lunardi, G. L., Becker, J. L., Maçada, A. C. G., \& Dolci, P. C. (2014). The impact of adopting IT governance on financial performance: An empirical analysis among Brazilian firms. International Journal of Accounting Information Systems, 15(1), 66-81.

Lunardi, G. L., Maçada, A. C. G., Becker, J. L., \& Van Grembergen, W. (2017). Antecedents of IT governance effectiveness: An empirical examination in Brazilian firms. Journal of Information Systems, 31(1), 41-57.

MacCurtain, S., Flood, P. C., Ramamoorthy, N., West, M. A. \& Dawson, J. F. (2010). The top management team, reflexivity, knowledge sharing and new product performance: A study of the Irish software industry. Creativity and Innovation Management, 19(3): 219-232.

Martin, N., Gregor, S., \& Hart, D. N. (2005). The social dimensions of business and IS/IT alignment: Case studies of six public-sector organizations. Australian Accounting Review, 15(3), 28-38.

Midavaine, J., Dolfsma, W., \& Aalbers, R. (2016). Board diversity and R\&D investment. Management Decision, 54(3), 558-569.

Miller, C. C., Burke, L. M., \& Glick, W. H. (1998). Cognitive diversity along upper-echelon executives: Implications for strategic decision processes. Strategic Management Journal, 19(1), 39-58.

Mohamed, N., \& Gian Singh, J. K. (2012). A conceptual framework for information technology governance effectiveness in private organizations. Information Management \& Computer Security, 20(2), 88-106.

Neirotti, P., \& Paolucci, E. (2007). Assessing the strategic value of Information Technology: An analysis on the insurance sector. Information \& Management, 44, 568-582.

Newby, M., Nguyen, T. H., \& Waring, T. S. (2014). Understanding customer relationship management technology adoption in small and medium-sized enterprises. Journal of Enterprise Information Management, 27(5), 541-580.

Nfuka, E. N., \& Rusu, L. (2011). The effect of critical success factors on IT governance performance. Industrial Management \& Data Systems, 111(9), 1418-1448.

Parent, M., \& Reich, B. H. (2009). Governing information technology risk. California Management Review, 51(3), 134-152.

Pelled, L. H. (1996). Demographic diversity, conflict, and work group outcomes: An intervening process theory. Organization Science, 7, 615-631. 
Pereira, R., \& Mira da Silva, M. (2012). Designing a new integrated IT governance and IT management framework based on both scientific and practitioner viewpoint. International Journal of Enterprise Information Systems, 8(4), 1-43.

Pérez Lorences, P., \& L. F. Garcia Avila. (2013). The evaluation and improvement of IT governance. Journal of Information Systems and Technology Management, 10(2), 219-234.

Peterson, R. (2004). Crafting information technology governance. Information Systems Management, 21(4), 7-22.

Qian, C., Cao, Q and Takeuchi, R. (2013). Top management team functional diversity and organizational innovation in China: The moderating effects of environment. Strategic Management Journal, 34(1), 11120.

Rivard, S., Raymond, L., \& Verreault, D. (2006). Resource-based view and competitive strategy: An integrated model of the contribution of information technology to firm performance. Journal of Strategic Information Systems, 15, 29-50.

Scheeren, A. W., Fontes-Filho, J. R., \& Tavares. E. (2013). Impacts of a relationship model of informational technology governance: An analysis of managerial perceptions in Brazil. Journal of Information Systems of Technology and Management, 10(3), 621-642.

Simons, T., Hope Pelled, L., \& Smith, K. A. (1999). Making use of difference: diversity, debate, and decision comprehensiveness in top management teams. Academy of Management Journal, 42(6), 662-673.

Simonsson, M., Johnson, P., \& Ekstedt, M. (2010). The effect of IT governance maturity on IT governance performance. Information Systems Management, 27, 1024.

Stone, W. S., \& Tudor, T. R. (2005). The effects of functional background experience, industry experience, generic executive management experience on perceived environmental uncertainty and firm performance. Advances in Competitiveness Research, 13(1), 1-8.

Surowiecki, J. (2005). The Wisdom of Crowds. New York, NY: Random House.

Talke, K., Salomo, S., \& Rost, K. (2010). How top management team diversity affects innovativeness and performance via the strategic choice to focus on innovation fields. Research Policy, 39(7), 907-918.

Tallon, P., Ramirez, R. V., \& Short, J. E. (2014). The information artefact in IT governance: Toward a theory of information governance. Journal of Management Information Systems, 30(3), 141-177.

Tallon, P. (2014). Do you see what I see? The search for consensus among executives' perceptions of IT business value. European Journal of Information Systems, 23, 306-325.

Taniman, C. A., \& O'Shannassy, T. F. (2015). Exploring the influence of chief executive officer professional development and work context on organisation performance: A multi-theoretic perspective. Journal of Management \& Organization, 21(5), 675-694.

Teo, T. SH. \& Pian, Y. (2003). A contingency perspective on Internet adoption and competitive advantage. European Journal of Information Systems, 12(2), 78-92.

Van Grembergen, W. \& De Haes, S. (2009). Enterprise governance of information technology - Achieving strategic alignment and value. New York, NY: Springer Science + Business Media.

Webb, P., Pollard, C., \& Ridley, G. (2006). Attempting to define IT governance: Wisdom or folly? Proceedings of the 39th Hawaii International Conference on System Sciences, IEEE Publishing, 1-10.

Weill, P., \& Ross, J. W. (2004). IT Governance: How top performers manage IT decision rights for superior results. Boston, MA: Harvard Business School Press.

Weill, P., \& Ross, J. W. (2005). A matrixed approach to designing IT governance. MIT Sloan Management Review, 46(2), 26-34. 
Wilkin, C. L., \& Chenhall, R. H. (2010). A review of IT governance: A taxonomy to inform accounting information systems. Journal of Information Systems, 24(2), 107-146.

Wilson, P., \& Pollard, C. (2009). Exploring IT governance in theory and practice in a large multi-national organization in Australia. Information Systems Management, 26, 98-109.

Wu, Y., Wei, Z, \& Liang, Q. (2011). Top management team diversity and strategic change. The moderating effects of pay imparity and organization slack. Journal of Organizational Change Management, 24(3), 267-281.

Xue, Y., Liang, H., \& Boulton, W. R. (2008). Information technology governance in information technology decision processes: The impact of investment characteristics, external environment, and internal context. MIS Quarterly, 32(1), 67-96.

Yeh, C-H., Lee, G-G., and Pai, J-C. (2012). How information system capability affects e-business information technology strategy implementation. Business Process Management Journal, 18(2), 197-218. 